\title{
Efficacy of two entomopathogenic nematode species as potential biocontrol agents against the rosaceae longhorned beetle, Osphranteria coerulescens, under laboratory conditions
}

\author{
Shervin SHARIFI ${ }^{1}$, Javad KARIMI ${ }^{1, *}$, Mojtaba HosSEINI ${ }^{1}$ and Mohammadreza ReZAPANAH ${ }^{2}$ \\ ${ }^{1}$ Biocontrol and Insect Pathology Laboratory, Department of Plant Protection, Faculty of Agriculture, \\ Ferdowsi University of Mashhad, Mashhad, Iran \\ ${ }^{2}$ Iranian Research Institute of Plant Protection, Tehran, Iran
}

Received: 26 March 2014; revised: 2 May 2014

Accepted for publication: 2 May 2014; available online: 13 June 2014

\begin{abstract}
Summary - Rosaceae longhorned beetle, Osphranteria coerulescens, is an important pest of fruit trees that attacks all fruit trees belonging to the family Rosaceae in cold regions of Iran. The potential efficacy of two species of entomopathogenic nematodes (EPN), Heterorhabditis bacteriophora and Steinernema carpocapsae, against last instar larvae of this pest was tested under laboratory conditions. In plate assays, the larvae were susceptible to both EPN species but were more susceptible to S. carpocapsae (65.0-97.5\% mortality) than $H$. bacteriophora (42.5-87.8\%). Both nematode species were able to penetrate and reproduce within $O$. coerulescens larvae, but reproduction rate for $H$. bacteriophora was higher than those of $S$. carpocapsae; however, the penetration rate for $S$. carpocapsae was greater than $H$. bacteriophora. In a migration test on agar plate, $S$. carpocapsae showed negligible attraction to the pest or to Galleria mellonella cues. However, H. bacteriophora was strongly attracted to the sector of Petri dishes containing larvae. In a test using apricot tree branches, both species of EPN passed from mass frass of $O$. coerulescens larvae in the tip of the branches, penetrated into the larval galleries, and located and killed the larvae of $O$. coerulescens in their natural habitat deep inside the branches. Our findings provide the first insight into the biocontrol efficacy of EPN against $O$. coerulescens larvae, and highlight their potential for the control of this pest. Field experiments are needed to evaluate their potential under the environmental conditions in which rosaceae longhorned beetle larvae are found.
\end{abstract}

Keywords - attraction, behaviour, Heterorhabditis bacteriophora, insect pathology, reproduction, Steinernema carpocapsae, virulence.

Rosaceae longhorned beetle, Osphranteria coerulescens Redtenbacher (Coleoptera: Cerambycidae), is an economically important pest of fruit trees in cold regions of Iran, Turkey and Syria. This beetle attacks all stone and pome fruit trees belonging to the family Rosaceae, as well as Japanese quince, oleaster, willow and elm (Rajabi, 1967). Adult beetles are active from late May to mid-June. Female insects prefer spring twigs for egg laying. Adult beetles lay a single egg into the upper part of twigs. Each insect lay 30-75 eggs and the average number is 52 (Sharifi et al., 1970). When larvae emerge, they bore through the cambium and hardwood (Behdad, 1974) penetrating into the centre of branches where they feed for a year (Rajabi, 1967). In thick branches and trunks, movement of $O$. coerulescens larvae and their feeding cause the branch to become fragile, and easily broken by wind (Esmaeili, 1983). The obvious sign of pest infestation is readily apparent when the tips of infested twigs break off and then larger branches break off as larval boring proceeds. The larva requires 11 months to develop while the pupa completes development during 22-24 days. This pest causes extensive damage to living rosaceous trees in Iran (Sharifi et al., 1970; Esmaeili, 1983).

Due to the cryptic behaviour of the larvae, control methods using chemical pesticides are problematic. Currently the key management tool for $O$. coerulescens consists of cutting the infested branches and destroying them by burning. Heavy infestations and associated economic losses warrant the development of sustainable and environmentally safe strategies, such as the use of biocontrol agents like entomopathogenic nematodes (EPN) against this cerambycid pest, especially in the late season.

* Corresponding author, e-mail: jkb@ferdowsi.um.ac.ir 
The EPN species of Steinernema Travassos and Heterorhabditis Poinar are obligate pathogens of insects (Poinar, 1979). These groups of insect pathogens have been studied extensively in different biocontrol programmes (Ehlers, 2001). The free-living infective juveniles (IJ) have to locate a potential host, penetrate through its cuticle or natural openings and establish in the host's body cavity (Koppenhöfer et al., 2007). In the insect haemocoel, the nematode releases its symbiotic bacteria from its intestine. The bacteria proliferate, producing toxins and metabolites that kill the insect host and prevent invasion by secondary organisms. The nematodes feed on the lysed tissues of the host and bacterial colonies (Griffin et al., 2005).

Several species of EPN have the ability to locate and kill insects in cryptic environments (Begley, 1990), and wood-boring larvae of insect pests like cerambycids could be suitable hosts. There are some studies on the biocontrol potential of EPN against wood borer pests. The pathogenicity of EPN has been assayed against larvae of Asian longhorned beetle, Anoplophora glabripennis (Liu et al., 1998; Solter et al., 2001; Fallon et al., 2004). Liu et al. (1998) stated that application of the Beijing strain of Steinernema carpocapsae via existing emergence holes of A. glabripennis caused $66.7 \%$ decrease in new emergence holes. Solter et al. (2001) showed the ability of Heterorhabditis marelatus to locate and kill larvae of Asian longhorned beetle within $30 \mathrm{~cm}$ larval galleries. Harvey et al. (2012) reported that two nematode species, $S$. carpocapsae and $H$. downesi, were able to infect larvae of the two-banded longhorn beetle, Rhagium bifasciatum, more than $4 \mathrm{~cm}$ deep within the wood.

The limited movement of $O$. coerulescens larvae and their protected environmental niche with high moisture within their galleries indicates that the use of EPN may be feasible, especially for cruiser species of EPN which forage actively for their hosts. There is an absence of data about the infectivity of EPN against $O$. coerulescens, so the main aims of the current project were to assay the EPN pathogenicity, reproduction and foraging behaviour, and to examine the ability of EPN to penetrate, locate and kill pest larvae within their galleries under laboratory conditions.

\section{Materials and methods}

\section{NEMATODES AND INSECTS}

Two commercially available EPN products, Larvanem ${ }^{\circledR}$ (H. bacteriophora) and Capsanem ${ }^{\circledR}$ (S. carpocapsae), were obtained from Koppert (Berkel en Rodenrijs, The
Netherlands). The late instar larvae of greater wax moth, Galleria mellonella, were reared and selected on the basis of mean weight and head capsule width. The nematodes were reared in the laboratory on $G$. mellonella larvae at $25 \pm 2{ }^{\circ} \mathrm{C}$, using the method described by Woodring \& Kaya (1988). The IJ that emerged from G. mellonella cadavers were collected using White (1927) traps and stored at $8^{\circ} \mathrm{C}$ in sterile distilled water in darkness (Kaya $\&$ Stock, 1997). Before being used in the experiment, the nematodes were allowed to acclimatise at room conditions for $1 \mathrm{~h}$ and their viability was checked under a stereomicroscope; IJ that were 1-2 weeks old were used in the assays. The nematodes were from separate batches to reduce differences in storage period.

The last instar larvae of $O$. coerulescens were collected from Astan Qods orchards on their susceptible hosts, apricot trees, in Mashhad, Razavi Khorasan province, North Eastern Iran $\left(36^{\circ} 4^{\prime} \mathrm{N}, 59^{\circ} 7^{\prime} \mathrm{E}\right)$. The larvae were transferred to the laboratory and further checked on the basis of larval morphology and mean weight.

\section{Plate assay}

To assess the virulence of $S$. carpocapsae and $H$. bacteriophora against the larvae of $O$. coerulescens, suspensions of IJ of each species were applied in $150 \mu \mathrm{l}$ of sterile distilled water into a $2.6 \mathrm{~cm}$ diam. plastic container lined with two layers of filter papers. An individual last instar larva of $O$. coerulescens was added to each container. Each nematode species was tested at rates of 5, 10, 25 and $50 \mathrm{IJ} \mathrm{larva}^{-1}$. The containers were sealed with parafilm to avoid dehydration and kept in an incubator at $25 \pm 2{ }^{\circ} \mathrm{C}$ and $16 \mathrm{~h}$ light $/ 8 \mathrm{~h}$ dark photoperiod during the entire experiment. Control treatments received only distilled water. Larval mortality was checked at $24 \mathrm{~h}$ intervals up to $72 \mathrm{~h}$ and dead larvae were removed, rinsed in distilled water and placed individually in Petri dishes containing moist filter paper. After 3 days each cadaver was dissected to confirm the presence of nematodes. Each treatment was replicated four times with five dishes for each replicate ( $=20$ dishes for each treatment) and the whole experiment was repeated twice.

\section{Penetration AND ReProduction of EPN ON $O$. COERULESCENS}

Forty last instar larvae of $O$. coerulescens were individually placed in separate $2.6 \mathrm{~cm}$ diam. plastic Petri dishes padded with a double layer of filter papers. Each larva was inoculated with each nematode isolate at concentra- 
tions of 5 or $25 \mathrm{IJ}$ in $150 \mu \mathrm{l}$ of sterile distilled water. The Petri dishes were kept as described above. After 3 days, the cadavers were picked up from the Petri dishes and ten cadavers that had been killed by nematodes were selected at random. Five cadavers were rinsed with distilled water to remove any nematodes from their surface, dissected in sterile distilled water under a stereomicroscope and the number of nematodes inside each cadaver was determined. Both EPN species complete a generation in a time not less than 4 days, so the numbers of nematodes within a host body were counted after 3 days (Susurluk, 2008; Susurluk et al., 2009), which gave the number of nematodes that had penetrated into the insect host.

The other five dead larvae were used to evaluate nematode reproduction. The larvae were rinsed in sterile distilled water to remove nematodes from their surface body then separately placed on White trap and incubated. The IJ exiting from the cadavers were collected over 20 days. The whole experiment was repeated twice.

\section{MigRATION BEHAVIOUR OF EPN}

To investigate the foraging behaviour of $H$. bacteriophora and $S$. carpocapsae, larvae of $O$. coerulescens and G. mellonella were used as hosts. The experimental unit was a $7 \mathrm{~cm}$ diam. glass Petri dish filled with a layer of approximately $0.5 \mathrm{~cm}$ of $2.5 \%$ agar. Each Petri dish was divided into four equal parts and a $1 \mathrm{~cm}$ diam. centred circle was drawn on the back of the dishes. In order to provide a chemical gradient, a single larva of $O$. coerulescens or G. mellonella was placed on one side of a quadrant of each Petri dish. The Petri dishes were covered with a lid and incubated. After $24 \mathrm{~h}$ the larvae were removed and $30 \mathrm{IJ}$ of each EPN species in $10 \mu \mathrm{l}$ sterile distilled water was added to the centre of the marked circle of each Petri dish. The plates were covered with a glass lid and kept for $3 \mathrm{~h}$ in the dark at $23 \pm 2^{\circ} \mathrm{C}$ to allow the nematodes to migrate. Then the number of IJ in each quadrant and chemical gradient formation point were counted under a stereomicroscope. For each host $(O$. coerulescens and $G$. mellonella) and EPN species, there were ten replicates and the experiment was repeated twice.

\section{BRANCH TEST}

The branch test was carried out to assess the ability of $S$. carpocapsae and $H$. bacteriophora to penetrate into the infested branches of apricot trees and infect the larvae of $O$. coerulescens in their larval galleries (their natural habitat). For this purpose, infested branches $c a$
$15-17 \mathrm{~cm}$ in length were collected from the orchards and transferred to the laboratory. The tips of the branches, where the larvae of $O$. coerulescens deposit their frass, were placed into $45 \mathrm{~cm}^{3}$ sponge pieces and a $1 \mathrm{~cm}$ diam. hole was made inside them. The EPN suspension at a concentration of $10000 \mathrm{IJ} \mathrm{ml}^{-1}$ was inoculated into each sponge piece. Then the branches were incubated horizontally in a controlled growth chamber at $25 \pm 2{ }^{\circ} \mathrm{C}$ and $16 \mathrm{~h} \mathrm{light} / 8 \mathrm{~h}$ dark photoperiod. Control treatments received only distilled water. After 5 days, the sponge pieces were removed and mortality of the larvae inside the branches was recorded. In order to confirm the presence of nematodes, cadavers were rinsed with distilled water and dissected. Each treatment had seven replicates with four branches for each replicate $(=28$ branches for each treatment) and the whole experiment was repeated twice.

\section{STATISTICAL ANALYSIS}

Data were corrected for control mortality (Abbott, 1925) and square-root transformed when necessary to meet assumptions of normality and homogeneity of variances. A two-way full factorial ANOVA (EPN species $x$ concentrations, with time as blocking) was used to determine the differences of larva mortality in the plate assay, penetration and reproduction tests. When ANOVA showed a significant effect $(P<0.05)$, Fisher's Protected LSD test was used to determine significance between mean values. In addition, in the plate assay, the $\mathrm{LC}_{50}$ values were determined using the Probit procedure for each EPN species. Parallelism test was applied to regression lines, and $\mathrm{LC}_{50}$ differences between nematode species were considered significant when $95 \%$ fiducial limits did not overlap.

In the branch test, larval mortality was analysed using the non-parametric Mann-Whitney $U$-test. In the migration test, data comparison was carried out based on the proportion of recovered IJ in the cue areas compared with all recovered IJ by the two-way full factorial ANOVA (EPN species $\times$ host species, with time as block). If significant differences were detected, the LSD test was used.

All statistical analyses were carried out using SAS software, version 9.1 (SAS Institute, 2002-2003).

\section{Results}

\section{Plate ASs ay}

The pathogenicity of two EPN species against the pest larvae were assessed in plate assays. The results indicated that the larvae of $O$. coerulescens were susceptible to both 
nematode species when EPN were applied at a concentration of $5 \mathrm{IJ}_{\text {larva }}{ }^{-1}$, which caused 42.5-65.0\% larval mortality after $72 \mathrm{~h}$ (Fig. 1C). Steinernema carpocapsae had greater virulence to the larvae of $O$. coerulescens and caused larval mortality of between 65.0 and $97.5 \%$ after $72 \mathrm{~h}$ (Fig. 1C). The maximum mortality of the larvae was caused by $S$. carpocapsae at a concentration of $50 \mathrm{IJ}$ larva $^{-1}(97.5 \%)$, while the minimum mortality rate was observed in the larvae treated with $H$. bacteriophora at $5 \mathrm{IJ} \mathrm{larva}^{-1}(42.5 \%)$ after $72 \mathrm{~h}$. Both EPN species caused larval mortality $24 \mathrm{~h}$ after treatment at all concentrations used, except for the treatment of $H$. bacteriophora in concentration of $5 \mathrm{IJ} \mathrm{larva}^{-1}$ (Fig. 1A). The overall mortality of the larvae of $O$. coerulescens $48 \mathrm{~h}$ after treatment with EPN ranged between $27.5 \%$ and $95.0 \%$ (Fig. 1B); $72 \mathrm{~h}$ after treatment, the mortality rate was $42.5-97.5 \%$ (Fig. 1C), which demonstrated an increase in larval mortality with increase in exposure time. The differences of larval mortality between the EPN species $(F=32.85$; $\mathrm{df}=1,48$; $P<0.0001)$ and $\mathrm{IJ}$ concentrations $(F=28.36 ; \mathrm{df}=3$, 48; $P<0.0001)$ were statistically significant. Also, significant differences between mortality were recorded between nematode species and concentrations $(F=7.83$; $\mathrm{df}=3,48 ; P<0.0002)$. The calculated $\mathrm{LC}_{50}$ for $S$. carpocapsae and $H$. bacteriophora on the pest larvae after $72 \mathrm{~h}$ were 2.7 and $9.0 \mathrm{IJ} \mathrm{larva}^{-1}$, respectively (Table 1 ). The $\mathrm{LC}_{50}$ values implied that $S$. carpocapsae was more virulent against the last instar larvae of $O$. coerulescens. The results of regression analysis showed that the regression lines were parallel $\left(x^{2}=0.588, \mathrm{df}=1, P<0.44\right)$, which indicates a similar effect of EPN species on $O$. coerulescens larvae.
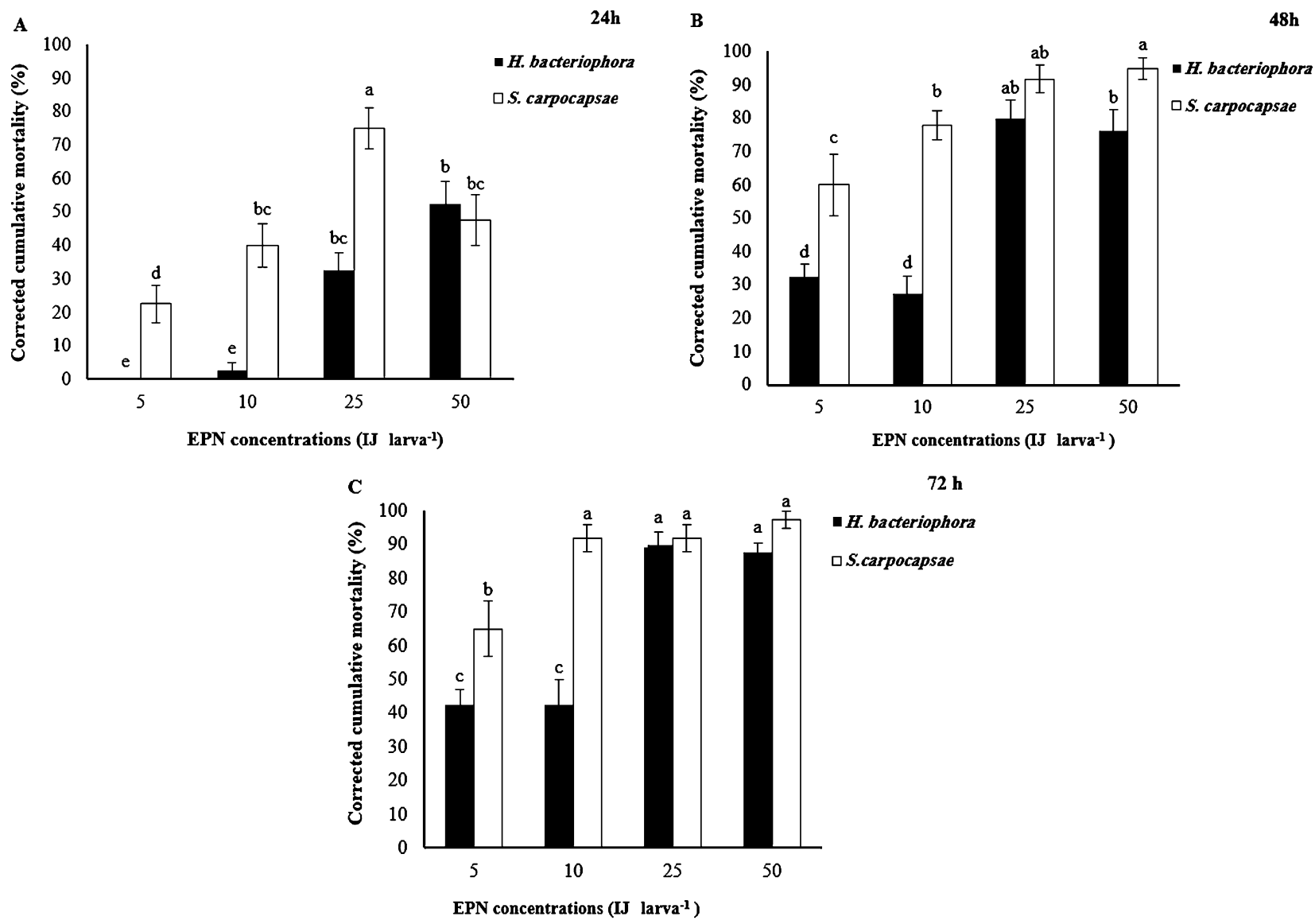

Fig. 1. Mortality of Ospheranteria coerulescens larvae after treatment with Heterorhabditis bacteriophora and Steinernema carpocapsae at concentrations of 5, 10, 25 and $50 \mathrm{IJ} \mathrm{larva}^{-1}$. A, B and C show the results at 24,48 and $72 \mathrm{~h}$ after inoculation, respectively. 
Table 1. Calculated $\mathrm{LC}_{50}$ values (IJ larva ${ }^{-1}$ ) for Heterorhabditis bacteriophora and Steinernema carpocapsae on last instar larvae of Osphranteria coerulescens.

\begin{tabular}{lcccccc}
\hline EPN species & Time after treatment $(\mathrm{h})$ & $\mathrm{LC}_{50}$ (95\% fiducial limit) & Intercept $\pm \mathrm{SE}$ & Slope $\pm \mathrm{SE}$ & $x^{2}(\mathrm{df}=2)$ & $P$ \\
\hline H. bacteriophora & 24 & $43.1(34.4-60.6)$ & $-4.54 \pm 0.75$ & $2.77 \pm 0.50$ & 1.75 & 0.41 \\
& 48 & $15.7(8.1-28.5)$ & $-2.23 \pm 0.54$ & $1.86 \pm 0.38$ & 7.55 & 0.02 \\
& 72 & $9.0(3.3-16.3)$ & $-1.85 \pm 0.45$ & $1.91 \pm 0.35$ & 5.21 & 0.073 \\
S. carpocapsae & 24 & $19.0(7.1-64.0)$ & $-1.14 \pm 0.34$ & $0.87 \pm 0.26$ & 13.00 & 0.0015 \\
& 48 & $3.1(0.9-5.2)$ & $-0.9 \pm 0.43$ & $1.55 \pm 0.37$ & 0.59 & 0.74 \\
& 72 & $2.7(0.4-6.0)$ & $-0.51 \pm 0.46$ & $1.48 \pm 0.42$ & 4.25 & 0.12 \\
\hline
\end{tabular}

Table 2. The number of infective juveniles of Heterorhabditis bacteriophora and Steinernema carpocapsae that penetrated into the larva of Osphranteria coerulescens and subsequently reproduced.

\begin{tabular}{|c|c|c|c|c|}
\hline $\begin{array}{l}\text { Application rate } \\
\left(\mathrm{IJ} \text { larva }^{-1}\right)\end{array}$ & EPN species & $\begin{array}{c}\text { Nematode invasion } \\
\left(\mathrm{IJ} \text { larva }^{-1} \pm \mathrm{SE}\right)\end{array}$ & $\begin{array}{l}\text { Nematode reproduction } \\
\quad\left(\mathrm{IJ} \text { larva }^{-1} \pm \mathrm{SE}\right)\end{array}$ & $\begin{array}{c}\text { Reproduction rate } \\
\text { (per invaded IJ) }\end{array}$ \\
\hline \multirow[t]{2}{*}{5} & H. bacteriophora & $1.5 \pm 0.16 \mathrm{c}$ & $333329 \pm 34431 \mathrm{a}$ & 222219 \\
\hline & S. carpocapsae & $2 \pm 0.21 \mathrm{c}$ & $45155 \pm 11196 \mathrm{a}$ & 22577 \\
\hline \multirow[t]{2}{*}{25} & H. bacteriophora & $5.8 \pm 0.61 b$ & $273468 \pm 31803 b$ & 47149 \\
\hline & S. carpocapsae & $18.3 \pm 0.71 \mathrm{a}$ & $71408 \pm 7145 b$ & 3902 \\
\hline
\end{tabular}

Different letters indicate significant differences at $P<0.05$.

\section{HOST PENETRATION AND REPRODUCTION}

The results of the penetration assay showed that both EPN species were able to penetrate and reproduce within the haemocoel of $O$. coerulescens larvae. The penetration of IJ was significantly affected by the nematode species $(F=160.19 ; \mathrm{df}=1,32 ; P<0.0001)$ and concentration of IJ $(F=402.24 ; \mathrm{df}=1,32 ; P<0.0001)$. Also the interaction between the nematode species and IJ concentration was significant $(F=136.49 ; \mathrm{df}=1$, 32; $P<0.0001)$. There was a positive correlation between the applied concentration of EPN and the number of IJ that invaded the pest larvae. By increasing the applied rate of IJ from 5 to $25 \mathrm{IJ} \mathrm{larva}^{-1}$, the number of IJ which penetrated into the larvae was increased. The highest penetration rate of IJ was recorded for $S$. carpocapsae at the concentration of $25 \mathrm{IJ} \mathrm{larva}^{-1}$, while the lowest invasion was observed with $H$. bacteriophora when applied at the concentration of $5 \mathrm{IJ} \mathrm{larva}^{-1}$.

The results of the reproduction test revealed significant differences among the reproduction potential of two nematode species $(F=97.92 ;$ df $=1,32 ; P<$ 0.0001 ) (Table 1). However, no statistically difference was detected between the IJ concentrations used $(F=0.46$; df $=1,32 ; P<0.5024)$. Moreover, the interaction between nematode species and IJ concentration was not significant $(F=3.02 ; \mathrm{df}=1,32 ; P<0.0918)$. The number of IJ produced per invaded IJ declined with increasing concentration of IJ from 5 to $25 \mathrm{IJ} \mathrm{larva}^{-1}$ for $H$. bacteriophora, while this value increased for $S$. carpocapsae. The highest reproduction rate was recorded for $H$. bacteriophora at the concentration of $5 \mathrm{IJ} \mathrm{larva}^{-1}$, in contrast to the lowest amount for $S$. carpocapsae at the same concentration (Table 2).

\section{MigRATION TEST}

The results of the migration test showed that there was a significant difference between two EPN species in the proportion of IJ that migrated towards host cues $(F=$ 455.33; $\mathrm{df}=1,73 ; P<0.05)$. The greatest proportion of migrated IJ was observed for $H$. bacteriophora toward $O$. coerulescens $(0.55 \pm 0.028)$, while the lowest proportion of migrated IJ was observed for $S$. carpocapsae toward O. coerulescens $(0.013 \pm 0.0044)$. In addition, there was a significant difference between the proportion of IJ that migrated towards the two host species $(F=4.45$; $\mathrm{df}=$ 1,$73 ; P=0.038$ ). Also, significant differences were recorded between the proportion of migrated IJ of the two EPN species and the two host species $(F=6.37$; $\mathrm{df}=1$, 73; $P=0.013$ ). 


\section{BRANCH TEST}

The results of this test indicated that both S. carpocapsae and $H$. bacteriophora passed from mass frass of $O$. coerulescens larvae in the tip of the branches, penetrated into the larval galleries, located and killed the larvae of $O$. coerulescens in their natural habitat deep inside the branches. IJ of $H$. bacteriophora caused greater mortality $(58.9 \%)$ than $S$. carpocapsae $(42.8 \%)$, but there were no statistically significant differences in larval mortality between the two nematode species (Kruskal-Wallis: $\left.x^{2}=2.867 ; \mathrm{df}=1,55 ; P>0.05\right)$.

\section{Discussion}

Our data provide the first insight into pathogenicity of two species of EPN against larvae of $O$. coerulescens. The laboratory experiments showed the efficacy of $H$. bacteriophora and $S$. carpocapsae to locate, penetrate and kill the larvae of $O$. coerulescens inside the galleries of apricot tree branches. Last instar larvae of $O$. coerulescens were highly susceptible to both species of EPN, causing mortalities of 42.5-97.5\% at concentrations of 5, 10, 25 and $50 \mathrm{IJ}$ larva $^{-1}$. The calculated $\mathrm{LC}_{50}$ for $H$. bacteriophora (9.0 IJ larva ${ }^{-1}$ ) was greater than these for $S$. carpocapsae $\left(2.7 \mathrm{IJ} \mathrm{larva}^{-1}\right)$ in agar plate assays, indicating a greater virulence of $S$. carpocapsae against $O$. coerulescens larvae. This finding supports the statement of Grewal et al. (1993a, b) that $S$. carpocapsae could effectively find pest larvae by cruising horizontally; $H$. bacteriophora is more effective to migrate and infect hosts moving vertically.

Previous work showed differences between virulence of EPN against cerambycid larvae. Fallon et al. (2004) examined pathogenicity of $S$. feltiae, $H$. marelatus, $S$. glaseri, $S$. riobrave and $S$. carpocapsae in a filter paper assay against Asian longhorned beetle, A. glabripennis. Their results revealed a marked susceptibility of the host larvae to nematode infection; $S$. feltiae and $S$. carpocapsae were the most effective causing 71 and $100 \%$ mortality, respectively. In a similar test, Fallon et al. (2006) investigated the efficacy of S. feltiae, $S$. carpocapsae, S. glaseri, S. riobrave, $H$. indica and $H$. marelatus on cottonwood borer, Plectrodera scalator, at concentrations of 10,50 and $100 \mathrm{IJ} \mathrm{larva}^{-1}$. They found similar results and stated that $S$. carpocapsae and S. feltiae were more virulent, causing 50 and $58 \%$ mortality of the larvae, respectively, while the mortality caused by $H$. marelatus was $12.9 \%$. Also Susurluk et al. (2009) indicated greater virulence of S. feltiae than
H. bacteriopghora against a cerambycid pest, Dorcadion pseudopreissi, a result that is in agreement with our data.

The pathogenicity of EPN is related to several biotic and abiotic factors, such as host invasion, penetration and reproduction (Kaya \& Gaugler, 1993). In the plate assays of the current work, both EPN and insect host were close to each other and the EPN did not have to move over a great distance. Differences in infectivity potentials of two EPN species might be explained by differences in their ability to penetrate the larvae. Greater virulence of $S$. carpocapsae could be related to the host finding behaviour of this species. However, in the case of H. bacteriophora, we could not attribute the difference among the mortalities with high concentrations to its host finding ability. Based on the early theory of host-finding behaviour by EPN (Campbell \& Gaugler, 1997), this is a cruiser species that moves and searches for its host (Gaugler \& Bilgrami, 2004). Therefore, in our assays at a given concentration the EPN used and searched all available space and a higher IJ concentration did not increase the mortality rates of insect pest larvae.

To be successful as an insect pathogen, the EPN species have to penetrate their host and reproduce. Based on Caroli et al. (1996), penetration rates are different between EPN species and are influenced by different hosts and substrates. In our study, S. carpocapsae showed greater penetration rates into the host larvae than $H$. bacteriophora. Our results agree with those of Susurluk et al. (2009), who showed that the greatest penetration of EPN species into D. pseudopreissi larvae was observed for $S$. carpocapsae and the lowest for $H$. bacteriophora. Also, the data indicated that the number of invaded IJ was linked to host mortality. In the present study, both EPN species penetrated and reproduced in the last instar larvae of the host and their IJ emerged from the host cadavers. However, reproduction of $H$. bacteriophora was significantly greater than that of $S$. carpocapsae. The larvae of $O$. coerulescens are large, a condition that provided a suitable host for reproduction of EPN. The potential of pest larvae to support rearing of EPN offspring is an important criterion when considering the possible role of EPN in biocontrol. However, our results of reproductive ability do not agree with the data of Susurluk et al. (2009) who reported the highest reproduction potential for $S$. carpocapsae and the lowest for H. bacteriophora in D. pseudopreissi larvae. Harvey et al. (2012) stated that two species of EPN, S. carpocapsae and $H$. downesi, reproduced in $R$. bifasciatum larvae successfully and the reproduction rate of $H$. bacteriophora was half that of $S$. carpocapsae. 
One possible reason for the difference in progeny results of EPN in larvae of $O$. coerulescens may be related to the type of reproduction of Heterorhabditids. Heterorhabditis bacteriophora is a hermaphrodite that produces more offspring than Steinernematids, which are amphimictic (Poinar, 1990; Mannion \& Jansson, 1992). Another reason for higher reproduction rate of $H$. bacteriophora in the host larvae might be due to size and behaviour of EPN species. Loya \& Hower (2003) also suggested that size and behaviour of nematode species may be a reason for variations in reproduction of $H$. bacteriophora in different life stages of the clover root curculio, Sitona hispidulus.

Because of the natural habitat of $O$. coerulescens larvae inside tree branches, investigation into the foraging behaviour of EPN is an important aspect for effective control of this pest. In addition, EPN have to migrate quickly to avoid sunlight and desiccation (Gaugler, 1988). EPN are likely to move in response to host cues like $\mathrm{CO}_{2}$ (Gaugler et al., 1980; Lewis et al., 1993) or gut fluids (Grewal et al., 1993a, b). They have different host-finding behaviour (Campbell \& Gaugler, 1997). Of the two species used in the current study, H. bacteriophora was clearly attracted to cues from $O$. coerulescens and G. mellonella. However, S. carpocapsae showed almost no response to both host cues. Similarly, Fallon et al. (2004) indicated that S. carpocapsae and $S$. riobrave do not show attraction to frass volatiles of A. glabripennis. Grewal et al. (1993a) stated that IJ of $H$. bacteriophora move directionally to host cues, so there is no relation between substrate and dispersal patterns of the nematode. By contrast, $S$. carpocapsae did not show a directional response to volatiles and, therefore, their movement pattern is related to the substrate in such way that decreases dispersal on a rough substrate (Grewal et al., 1994). The poor response to chemical cues is characteristic of $S$. carpocapsae. Lewis et al. (1992, 1993) showed that $S$. carpocapsae did not respond to Spodoptera exigua and Popillia japonica frass and host cuticles; nor did it respond to volatiles from G. mellonella larvae. Our results support this lack of response by $S$. carpocapsae. In general, higher numbers of $H$. bacteriophora IJ migrated toward $O$. coerulescens larvae than $G$. mellonella larvae. Many studies have showed differences in $\mathrm{CO}_{2}$ production by different insects (e.g., Gaugler et al., 1991; Ramos-Rodríguez et al., 2007).

In the apricot tree branch test, there was no significant difference between virulence of both EPN species. The late instar larvae of $O$. coerulescens were in a gallery at a depth of approximately $5 \mathrm{~cm}$ from the tip of the branch and IJ have to move this distance to reach the larvae. The aggregation of the pest frass at the tip of the branch is a cue for directional movement of the IJ. Wilson et al. (2012) re-examined the supposed characteristic foraging behaviour of $S$. carpocapsae. The IJ of this species disperse over short distances, aggregate near the soil surface and react poorly to chemical cues, so occurrence of foraging behaviour may be low. In many papers it was reported that $S$. carpocapsae provided suitable control of wood-boring pest beetles in both laboratory and field experiments (Fallon et al., 2004; Dillon et al., 2006; Harvey et al., 2012). One possible reason for variation between results of attraction and branch tests is the difference between substrate textures. IJ dispersal has been reported to be markedly affected by substrate texture (Georgis \& Poinar, 1983; Molyneux \& Bedding, 1984; Portillo-Aguilar et al., 1999; Jabbour \& Barbercheck, 2008). Many studies were carried out to test mobility of S. carpocapsae in sandy soil (e.g., Moyle \& Kaya, 1981; Schroeder \& Beavers, 1987; Grewal et al., 1994, 1999) or agar (e.g., Lewis et al., 1992; Campbell \& Gaugler, 1993; Grewal et al., 1994, 1999; Lewis \& Gaugler, 1994). Wilson et al. (2012) stated that one reason for the supposed relative immobile behaviour of $S$. carpocapsae was inappropriate test substrates used in those tests. The tree branches used in our work provide more appropriate substrates for movement tests.

One other possible reason for this difference in our data and the previously reported behaviour of $S$. carpocapsae is the existence of the larvae of $O$. coerulescens inside the branch where its feeding causes vibration; this may provide a cue for the nematode. Such a cue would be absent in agar plate assays. Torr et al. (2004) showed that $S$. carpocapsae had strong response to a wide range of vibrational cues. Recently Kruitbos et al. (2010) stated that $S$. carpocapsae is adapted to being active in habitats other than mineral soils (e.g., peat, leaf litter, bark or wood). Our results support this finding and also fit with the habitat preferences of this species; S. carpocapsae prefer woodlands where their soil habitats have much higher organic matter contents (Hominick, 2002).

Overall, EPN have potential to be used against $O$. coerulescens larvae as a management tool in combination with other control methods. One possible method is to apply EPN after cutting the infested branches. While the larvae of $O$. coerulescens showed highly susceptibility to both EPN in the laboratory condition, the feeding niches of this pest occur in twigs or, later, in tree trunks. This could be a challenge due to the high sensitivity 
of EPN to UV light and desiccating conditions. Our results show that EPN can enter into insect galleries and kill insect larvae inside but records of successful field control are scarce and limited to those cases of pests that produce galleries in roots. For above ground cases, EPN have to find entry to the galleries before they are killed by adverse environmental conditions. Therefore, implementing EPN as part of control approach for $O$. coerulescens necessitates resolving these questions. What is the best application method of EPN? Which methods will provide suitable condition to protect EPN from extreme conditions? The last method might include some critical issues like application time and using a cover after treatment.

\section{Acknowledgements}

The authors thank Prof. Randy Gaugler for his help and advice. The financial support by the research deputy of Ferdowsi University of Mashhad is gratefully acknowledged. We wish to thank Prof. Roland Perry for his help with manuscript editing, and two anonymous reviewers for their comments.

\section{References}

Akhurst, R.J. \& Boemaere, N.E. (1990). Biology and taxonomy of Xenorhabdus. In: Gaugler, R. \& Kaya, H.K. (Eds). Entomopathogenic nematodes in biological control. Boca Raton, FL, USA, CRC Press, pp. 75-87.

Begley, J.W. (1990). Efficacy against insects in habitats other than the soil. In: Gaugler, R. \& Kaya, H.K. (Eds). Entomopathogenic nematodes in biological control. Boca Raton, FL, USA, CRC Press, pp. 215-231.

Behdad, E. (1984). Pests of fruit trees in Iran. Tehran, Iran, Plant Pests and Diseases Research Institute.

Burman, M. (1982). Neoaplectana carpocapsae: toxin production by axenic insect parasitic nematodes. Nematologica 28, 62-70.

Campbell, J.F. \& Gaugler, R. (1993). Nictation behaviour and its ecological implication in the host search strategies of entomopathogenic nematodes (Heterorhabditidae and Steinernematidae). Behaviour 126, 155-169.

Campbell, J.F. \& Gaugler, R.R. (1997). Inter-specific variation in entomopathogenic nematode foraging strategy: dichotomy or variation along a continuum? Fundamental and Applied Nematology 20, 393-398.

Caroli, L., Glazer, I. \& Gaugler, R. (1996). Entomopathogenic nematode infectivity assay: multi variable comparison of pen- etration into different hosts. Biocontrol Science and Technology 6, 227-233.

Dillon, A.B., Ward, D., Downes, M.J. \& Griffin, C.T. (2006). Suppression of the large pine weevil Hylobius abietis (Coleoptera: Curculionidae) in pine stumps by entomopathogenic nematodes with different foraging strategies. Biological Control 38, 217-227.

Ehlers, R.-U. (2001). Mass production of entomopathogenic nematodes for plant protection. Applied Microbiology and Biotechnology 56, 623-633.

Esmaeili, M. (1983). Important pests of fruit trees. Tehran, Iran, Sepehr Publishing Center.

Fallon, D.J., Solter, L.F., Keena, M., McManus, M., Cate, J.R. \& Hanks, L.M. (2004). Susceptibility of Asian longhorned beetle, Anoplophora glabripennis (Motchulsky) (Coleoptera: Cerambycidae) to entomopathogenic nematodes. Biological Control 30, 430-438.

Fallon, D.J., Solter, L.F., Bauer, L.S., Miller, D.L., Cate, J.R. \& McManus, M.L. (2006). Effect of entomopathogenic nematodes on Plectrodera scalator (Fabricius) (Coleoptera: Cerambycidae). Journal of Invertebrate Pathology 92, 55-57.

Gaugler, R. (1988). Ecological considerations in the biological control of soil-inhabiting insects with entomopathogenic nematodes. Agriculture Ecosystems \& Environment 24, 351360.

Gaugler, R., Lebeck, L., Nakagaki, B. \& Boush, G.M. (1980). Orientation of the entomogenous nematode Neoaplectana carpocapsae to carbon dioxide. Environmental Entomology 9, 649-652.

Gaugler, R., Campbell, J.F. \& Gupta, P. (1991). Characterization and basis of enhanced host finding in a genetically improved strain of Steinernema carpocapsae. Journal of Invertebrate Pathology 57, 234-241.

Grewal, P.S., Gaugler, R. \& Lewis, E.E. (1993a). Host recognition by entomopathogenic nematodes during contact with insect gut contents. Journal of Parasitology 79, 495-503.

Grewal, P.S., Gaugler, R. \& Selvan, S. (1993b). Host recognition by entomopathogenic nematodes: behavioral response to contact with host faeces. Journal of Chemical Ecology 119, 1219-1231.

Grewal, P.S., Lewis, E.E., Gaugler, R. \& Campbell, J.F. (1994). Host finding behaviour as a predictor of foraging strategy in entomopathogenic nematodes. Parasitology 108, 207-215.

Grewal, P.S., Converse, V. \& Georgis, R. (1999). Influence of production and bioassay methodes on infectivity of two ambush foragers (Nematoda: Steinernematidae). Journal of Invertebrate Pathology 73, 40-44.

Griffin, C.T., Boemare, N.E. \& Lewis, E.E. (2005). Biology and behaviour. In: Grewal, P.S., Ehlers, R.-U. \& Shapiro-Ilan, D. (Eds). Nematodes as biocontrol agents. Wallingford, UK, CABI Publishing, pp. 47-64.

Harvey, C.D., Alameen, K.M. \& Griffin, C.T. (2012). The impact of entomopathogenic nematodes on a non-target, serviceproviding longhorn beetle is limited by targeted application 
when controlling forestry pest Hylobius abietis. Biological Control 62, 173-182.

Hominick, W.M. (2002). Biogeography. In: Gaugler, R. (Ed.). Entomopathogenic nematology. Wallingford, UK, CABI Publishing, pp. 115-144.

Kaya, H.K. (1985). Susceptibility of early larval stage of Pseudaletia unipuncta and Spodoptera exigua (Lepidoptera: Noctuidae) to the entomopathogenic nematodes Steinernema feltiae (Rhabditida: Steinernematidae). Journal of Invertebrate Pathology 46, 58-62.

Kaya, H.K. \& Gaugler, R. (1993). Entomopathogenic nematodes. Annual Review of Eentomology 38, 181-206.

Kaya, H.K. \& Stock, S.P. (1997). Techniques in insect nematology. Manual of techniques in insect pathology. New York, NY, USA, Academic Press, pp. 281-324.

Koppenhöfer, A.M., Grewal, P.S. \& Fuzy, E.M. (2007). Differences in penetration routes and establishment rates of four entomopathogenic nematode species into four white grub species. Journal of Invertebrate Pathology 94, 184-195.

Kruitbos, L.M., Heritage, S.E., Hapca, S. \& Wilson, M.J. (2010). The influence of habitat quality on the foraging strategies of the entomopathogenic nematodes Steinernema carpocapsae and Heterorhabditis megidis. Parasitology 137, 303-309.

Lewis, E.E. \& Gaugler, R. (1994). Entomopathogenic nematode (Rhabdita: Steinernematidae) sex ratio relates to foraging strategy. Journal of Invertebrate Pathology 64, 238-242.

Lewis, E.E., Gaugler, R. \& Harrison, R. (1992). Entomopathogenic nematode host finding: response to host contact cues by cruise and ambush foragers. Parasitology 105, 103-107.

Lewis, E.E., Gaugler, R. \& Harrison, R. (1993). Response of cruiser and ambusher entomopathogenic nematodes (Steinernematidae) to host volatile cues. Canadian Journal of Zoology 71, 765-769.

Liu, H.X., Chang, Q., Ma, F. \& Liu, H.X. (1998). Field experiment of Anoplophora glabripennis and Melanophila decastigma control with pathogenic nematode Steinernema carpocapsae. Ningxia Journal of Agricultural and Forestry Science and Technology 5, 15-17.

Loya, L.J. \& Hower, J.A.A. (2003). Infectivity and reproduction potential of the Oswego strain of Heterorhabditis bacteriophora associated with life stages of the clover root curculio, Sitona hispidulus. Journal of Invertebrate Pathology 72, 6372 .

Mannion, C.M. \& Jansson, R.K. (1992). Comparison of ten entomopathogenic nematodes for control of sweet potato weevil (Coleoptera: Apionidae). Journal of Economic Entomology 85, 1642-1650.

Moyle, P.L. \& Kaya, H.K. (1981). Dispersal and infectivity of the entomogenous nematode, Neoaplectana carpocapsae Weiser (Rhabditida: Steinernematidae) in sand. Journal of Nematology 13, 295-300.
Poinar Jr., G.O. (1979). Nematodes for biological control of insects. Boca Raton, FL, USA, CRC Press.

Poinar Jr., G.O. (1990). Taxonomy and biology of Steinernematidae and Heterorhabditidae. In: Gaugler, R. \& Kaya, H.K. (Eds). Entomopathogenic nematodes in biological control. Boca Raton, FL, USA, CRC Press, pp. 23-61.

Rajabi, G. (1987). Destructive insect pests of fruit trees in cold regions of Iran. Tehran, Iran, Research Institute of Plant Pests and Diseases Publication.

Ramos-Rodríguez, O., Campbell, J.F., Lewis, E.E., ShapiroIlan, D.I. \& Ramaswami, S.B. (2007). Dynamics of carbon dioxide release from insects infected with entomopathogenic nematodes. Journal of Invertebrate Pathology 94, 64-69.

Schroeder, W.J. \& Beavers, J.B. (1987). Movement of the entomogenous nematodes of the families Heterorhabditidae and Steinernematidae in soil. Journal of Nematology 19, 257259.

Sharifi, S., Javadi, I. \& Chemsak, J.A. (1970). Biology of the Rosaceae branch borer, Osphranteria coerulescens (Coleoptera: Cerambycidae). Annals of the Entomological Society of America 63, 1515-1520.

Solter, L.F., Keena, M., Cate, J.R., McManus, M.L. \& Hanks, L.M. (2001). Infectivity of four species of nematodes (Rhabditoidea: Steinernematidae, Heterorhabditidae) to the Asian longhorn beetle, Anoplophora glabripennis (Motchulsky) (Coleoptera: Cerambycidae). Biocontrol Science and Technology 11, 547-552.

Susurluk, A. (2008). Potential of the entomopathogenic nematodes, Steinernema feltiae, S. weiseri and Heterorhabditis bacteriophora for the biological control of the sugar beet weevil Bothynoderes punctiventris (Coleoptera: Curculionidae). Journal of Pest Science 81, 221-225.

Susurluk, I.A., Kumral, N.A., Peters, A., Bilgili, U. \& Aclkgoz, E. (2009). Pathogenicity, reproduction and foraging behaviours of some entomopathogenic nematodes on a new turf pest, Dorcadion pseudopreissi (Coleoptera; Cerambycidae). Biocontrol Science and Technology 19, 585-594.

Torr, P., Heritage, S. \& Wilson, M.J. (2004). Vibrations as a novel signal for host location by parasitic nematodes. International Journal for Parasitology 34, 997-999.

White, G.F. (1927). A method for obtaining infective nematode larvae from cultures. Science 66, 302-303.

Wilson, M.J., Ehlers, R.-U. \& Glazer, I. (2012). Entomopathogenic nematode foraging strategies - is Steinernema carpocapsae really an ambush forager? Nematology 14, 389394.

Woodring, J.L. \& Kaya, H.K. (1988). Steinernematid and Heterorhabditid nematodes: a hand book of techniques. Fayetteville, AR, USA, Arkansas Agricultural Experiment Station, Southern Cooperative Bulletin. 